\title{
ФИЗИКО-МАТЕМАТИЧЕСКОЕ ОБРАЗОВАНИЕ
}

\author{
УДК 535.016
}

ББК 22.343

DOI: $10.33065 / 2307-1052-2018-4-26-78-91$

\section{Разработка и внедрение электронного курса для дисциплин по выбору «Введение в нанофизику» и «Нанотехнологии и наноэлектроника» в педагогическом университете}

\author{
Алтунин Константин Константинович, \\ кандидат физико-математических наук, доцент кафедры физики и технических дисии- \\ плин, Ульяновский государственный педагогический университет имени И.Н. Ульянова, \\ 2. Ульяновск, Россия
}

\begin{abstract}
Аннотация. Представлены результаты внедрения электронного курса для поддержки изучения учебных дисциплин по выбору «Введение в нанофизику» и «Нанотехнологии и наноэлектроника» в образовательный процесс университета. Обсуждается необходимость освоения физических основ нанотехнологий и наноэлектроники бакалаврами и магистрами физико-математического профиля. Предложена модульно-тематическая организация структуры электронных курсов, созданная в системе управления обучением MOODLE. Описаны результаты педагогического эксперимента по внедрению электронных курсов «Введение в нанофизику» и «Нанотехнологии и наноэлектроника» в образовательный процесс педагогического университета. Получены доказательства высокой эффективности использования электронных ресурсов в преподавании нанофизики, наноэлектроники и нанотехнологий.

Ключевые слова: нанофизика, физика наноструктур, наноэлектроника, нанотехнологии, электронный учебный курс, электронный образовательный ресурс, физические принципы наноэлектроники, физические основы нанотехнологии, теоретические знания, педагогический эксперимент.
\end{abstract}

\section{Development and Implementation of Electronic Courses «Introduction to} Nano-physics» and «Nano-technology and Nano-electronics» in Pedagogical Universities

\section{Altunin Konstantin K.,}

Candidate of Physical and Mathematical Sciences, Associate Professor, Department of Physics and Technical Disciplines, Ulyanovsk State Pedagogical University named after I.N. Ulyanov, Ulyanovsk, Russia 
Abstract. The article shows the results of the introduction of an electronic course to study such academic disciplines as «Introduction to Nano-physics» and «Nano-technology and Nano-electronics». The article discusses the necessity of mastering the physical bases of nano-technology and nano-electronics. A modular and thematic organization of the structure of electronic courses, created in the MOODLE learning management system, is proposed. The results of the pedagogical experiment are described as the author has obtained the evidence of the high efficiency of using electronic resources in teaching nano-physics, nano-electronics and nano-technology.

Keywords: nano-physics, physics of nano-structures, nano-electronics, nano-technology, electronic training course, electronic educational resource, physical principles of nano-electronics, physical fundamentals of nano-technology, theoretical knowledge, pedagogical experiment.

Одним из приоритетных направлений в области современных физико-технических исследований являются нанотехнологии. В настоящее время электронная техника приближается к широкому использованию разнообразных нанотехнологических приборов и устройств. В связи с интенсивным развитием нанотехнологии становится актуальным развитие квантовой теории, позволяющей адекватно описывать оптические явления в наносистемах. В результате появления современных методов проектирования наносистем появились обширные классы новых нанообъектов: планарных наноструктур, наноструктурных плёнок и плёночных наноструктурных покрытий, с характерными размерами, лежащими в нанометровом диапазоне. Проектируются и новые приборы на основе наноструктур.

В связи с быстрым ростом информации в области нанотехнологий, постоянным уменьшением размеров элементов современной электроники вплоть до нанометровых размеров, появлением новых наноэлектронных приборов, устройств и изделий, необходима разработка и внедрение электронных курсов по физическим основам нанотехнологии и наноэлектронике в образовательный процесс университетов. Важно организовать систематизированное использование научной информации по нанотехнологиям в педагогическом процессе, обеспечить доступ студентов к новым микроэлектронным технологиям, приборам и изделиям. Все это можно сделать в рамках и за счет средств электронного курса, разработанного в MOODLE и внедренного в процесс преподавания дисциплин по выбору «Нанотехнологии и наноэлектроника» и «Введение в нанофизику».

В настоящее время электронное обучение находит применение в образовательном процессе для получения второго высшего образования, в дополнительном образовании или при переподготовке специалистов. В российском образовании технологии электронного обучения внедряются в качестве дополнения к очному образованию.

Главное достоинство использования электронных курсов в обучении заключается в возможности выбора студентами индивидуальной скорости освоения учебной дисциплины.

Объектом исследования является процесс усвоения материала дисциплин по выбору «Нанотехнологии и наноэлектроника» и «Введение в нанофизику» студентами педагогического университета.

Предмет исследования: влияние факта внедрения электронного курса на успеваемость студентов, изучающих дисциплины по выбору «Нанотехнологии и наноэлектроника» и «Введение в нанофизику». 
Целью данной работы является разработка и внедрение электронного курса для формирования знаний, умений и навыков по дисциплинам по выбору «Нанотехнологии и наноэлектроника» и «Введение в нанофизику».

Гипотеза исследования состоит в предположении, что после внедрения электронного курса, разработанного в системе MOODLE, в процесс преподавания дисциплин по выбору «Нанотехнологии и наноэлектроника» и «Введение в нанофизику» уровень обученности студентов возрастёт.

В последние годы наблюдается рост интереса к проблеме использования электронных ресурсов в преподавании вообще и в преподавании физических дисциплин в частности. Так, подвергнута анализу эффективность применения электронных учебников [Байнева, Байнев 2011: 38], определена специфика использования электронных ресурсов в российских вузах, рассмотрены приоритеты развития электронного образования, выявлены проблемы использования электронных ресурсов в образовательном процессе для смешанной формы обучения [Дворянчиков, Калашникова, Печникова, Фролова 2016]. Получены доказательства возможности повышения эффективности обучения на 60 \% при использовании электронных курсов в образовательном процессе [Осипов 2012].

Выявлены особенности структуры образовательных программ подготовки магистров по направлениям в сфере наноэлетроники в университетах Великобритании. Показана актуальность проектирования курсов, перспективных для развития наноэлектроники, нанонауки и электронной промышленности [Михайлюк 2012]. Проанализировано современное состояние подготовки специалистов в области нанотехнологий в России [Морев 2011]. Ученые обсуждают цели и содержание дисциплины «Наноматериалы и нанотехнологии» в технических университетах, а также подходы к преподаванию разделов, связанных с изучением физических и химических свойств фуллеренов и углеродных нанотрубок, возможности использования приёмов нанотехнологии для улучшения параметров сегнетоэлектрических керамических материалов [Приседский, Волкова 2018]. Рассматриваются и обосновываются подходы к отбору и освоению содержания проблематики современных наукоёмких технологий в условиях уровневой подготовки педагогических кадров по физике, с отражением в содержании теоретической и экспериментальной подготовки будущих учителей ключевых концептов нанофизики [Остроумова 2014]. Выявлены основные проблемы подготовки и повышения квалификации специалистов в области нанотехнологий [Надеждин 2010: 22].

Особенности создания электронного образовательного ресурса по курсам «Нанооптика» и «Нанотехнологии оптических материалов» в системе управления обучением MOODLE для студентов физико-математического факультета, результаты разработки и внедрения тем, связанных с изучением физических свойств наноматериалов, в частности, наноматериалов с квазинулевой диэлектрической проницаемостью, в электронный курс и др. были рассмотрены в ряде работ автора статьи [Алтунин 2017; Алтунин, Макушкина 2018]. Автором разработано также информационное сопровождение темы из «Нанооптики», посвященной изучению приближения эффективной среды [Алтунин 2018], интерактивная презентация по элементам наноплазмоники в курсе физики, которые также могут быть использованы в специальных курсах «Нанооптика» и «Оптика тонкослойных и наноструктурных покрытий» [Алтунин, Низамова 2018].

В настоящее время начинают появляться электронные курсы по наукам о наноматериалах и нанотехнологиях [Юнусов 2016], разработан курс «Введение в нанотехнологии» в системе дистанционного обучения, включающий совокупность 
разработок ведущих мировых специалистов в области гуманитарного освоения нанотехнологической модернизации [Чванова 2014].

В данной статье рассматриваются результаты преподавания дисциплин по выбору «Нанотехнологии и наноэлектроника» и «Введение в нанофизику» в Ульяновском государственном педагогическом университете им. И. Н. Ульянова. Указанные дисциплины читаются автором с использованием информационной поддержки в виде электронного курса, созданного в системе управления обучением MOODLE.

При освоении программы студенты должны сделать выбор из ряда следующих учебных дисциплин: «Введение в нанофизику», «Нанотехнологии и наноэлектроника», «Физика полупроводников и диэлектриков», «Теория гравитации». Дисциплины «Введение в нанофизику», «Нанотехнологии и наноэлектроника» являются однотипными по содержанию, но читаются разными преподавателями. Дисциплина по выбору «Физика полупроводников и диэлектриков» имеет ярко выраженную экспериментальную направленность, связанную с работой с полупроводниковыми схемами и приборами. Дисциплина по выбору «Теория гравитации» имеет теоретическую направленность и связана с изучением математического аппарата тензорного исчисления, применяемого в этой области.

В статье рассматривается процесс разработки и внедрения электронного образовательного ресурса, связанного с изучением физики наноструктур, физических основ нанотехнологии, физических принципов наноэлектроники. Разработка такого электронного курса является актуальной задачей в современном физическом образовании для формирования у обучающихся системы физико-технических знаний и знаний по нанотехнологиям и наноэлектронике.

Электронный курс «Введение в нанофизику» расположен в категории курсов «Физика» факультета физико-математического и технологического образования. На рис. 1 изображена входная страница электронного курса «Введение в нанофизику», созданного в системе управления обучением MOODLE на сайте ФГБОУ ВО «УлГПУ им. И. Н. Ульянова».

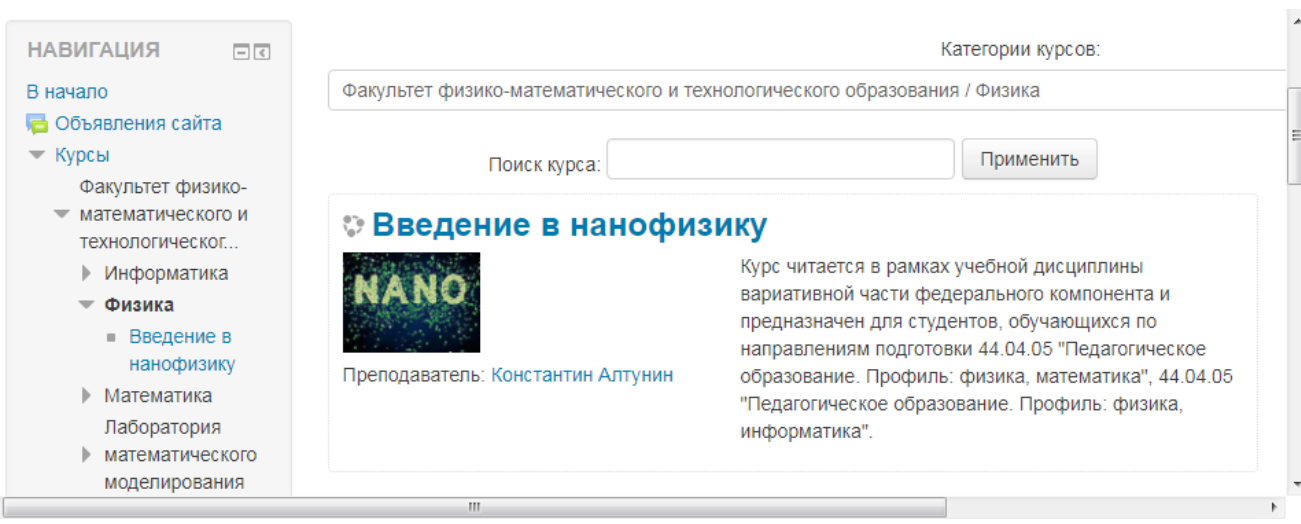

Рис. 1. Входная страница электронного курса «Введение в нанофизику», созданного в системе управления обучением MOODLE.

На рис. 2 изображена вводная часть электронного курса «Введение в нанофизику», созданного в системе управления обучением MOODLE. Вводная часть курса содержит основную литературу для изучения в рамках курса. 


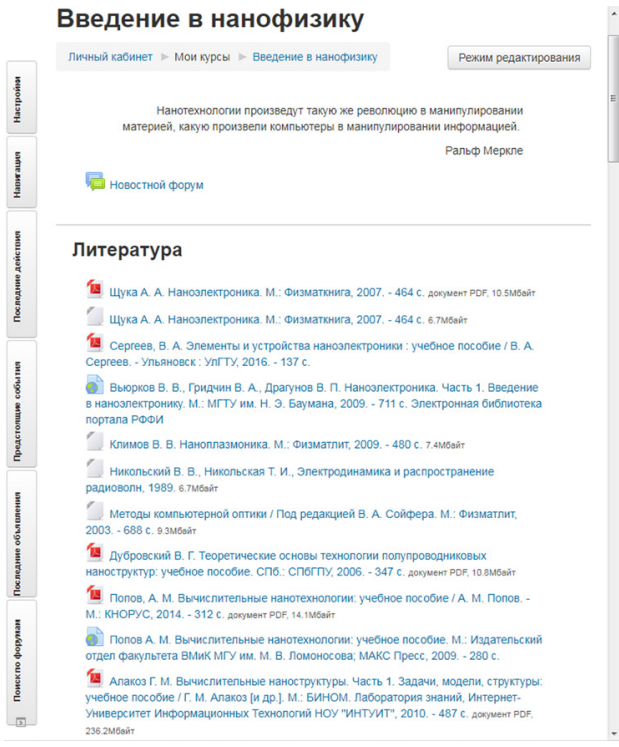

Рис. 2. Вводная часть электронного курса «Введение в нанофизику», созданного в системе управления обучением MOODLE.
Электронный курс «Введение в нанофизику» в системе управления обучением MOODLE представляет собой совокупность тематических модулей, в которых заключён необходимый теоретический материал, справочные таблицы, рисунки, информационно-справочные материалы по физическим основам нанотехнологии и наноэлектронике, тесты из общего банка тестовых заданий электронного курса и элементы навигации. Для более глубокого изучения тематического содержания модулей студенты могут воспользоваться гиперссылками на внутренние и внешние источники информации по физическим основам нанотехнологии и наноэлектронике в глобальной сети Интернет. Основным терминам и понятиям нанотехнологии и наноэлектроники в электронном курсе «Введение в нанофизику» посвящены гиперссылки на статьи глоссария. Весь теоретический материал по физическим основам нанотехнологии и наноэлектронике разделён на модули, каждый из которых доступен для изучения определённый период времени. В свою очередь, модули могут подразделяться на подтемы, лекции, семинары, включать гипертекстовые страницы с теоретическим материалом, гипертекстовые страницы с практическими задачами, коллективные обсуждения в wiki-элементах, дидактические материалы к занятиям, ряд заданий для самостоятельной работы, гиперссылки на рекомендуемые учебные издания и учебники по физике, гиперссылки на внешние электронные источники информации. Электронный курс «Введение в нанофизику» позволяет использовать видеофайлы и внешние видеоролики, графики, изображения и элементы форматирования. Материал каждой подтемы создан в виде гипертекстовой страницы. Приведены примеры решения задач по теоретическим основам физики наноструктур в рамках квантовой механики, есть задачи с ответами для самостоятельного решения и задачи без ответов для проведения проверочных и контрольных работ.

На рис. 3 изображена первая тема электронного курса «Введение в нанофизику», созданного в системе управления обучением MOODLE.

На рис. 4 изображена страница из второй, третьей и четвёртой тем электронного курса «Введение в нанофизику», созданного в системе управления обучением MOODLE.

Внедрение электронного курса по дисциплинам по выбору «Введение в нанофизику» и «Нанотехнологии и наноэлектроника» в образовательный процесс педагогического университета.

Педагогический эксперимент проводился на факультете физико-математического и технологического образования со студентами групп по профилям подготовки «Физика. Математика» и «Физика. Информатика». Суть педагогического эксперимента сводится к сопоставлению результатов изучения курса, связанного с нанотехнологиями и наноэлектроникой, без применения и с применением электронных информационных средств обучения. 
1. Квантовомеханические основы формирования наноструктур. Методы и принципы наноэлектроники. Принцип размерного квантования

(19) содержание темы 1

Нанотехнологии - это совокупность фундаментапьных и прикладных исспедований и разработок, направленных на познание специфики поведении ение его свойствами в интервале его характерных размерс примерно от 1 до $100 \mathrm{HM}$, где уникальные явления позволяіст реализовать .

'四 введение в нанофизику пехция

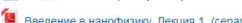

囱 вөедение в нанофизику. Лекция 2. Многообразие наносисте

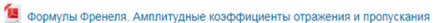

興 вводная лекция (Преподаватели, тьюторы, студенты)

[5] Учебно-научный фильм "Наноинженерия"

'四 моисеев С. Г., виноградов С. в. основы нанофизики: методические указания к практическим занятиям по дисциплине "Веедение в нанофизику". Ульяновск. УлГТУ

бщ уравнение Шредингера. Частица в потенциапьной яме - мамаев Ю. А. Туннельный эффект

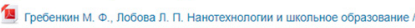

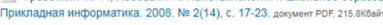

'园 строкова В. В. наносистемы в строительнои материаловедении: учебное пособие Строкова В. В., Жерновский И. В., Череватова А. В. Белгород: Белгородский досммнт PDF, 71. 1мбай

P8. введение в нанофизику пехция 1 . (poptx)

диэлектрическая проницаемость благородных металлов в модели друде-Лоренца

Рис. 3. Первая тема электронного курса «Введение в нанофизику», созданного в системе управления обучением MOODLE.

\section{2. Физика и технология изготовления} полупроводниковых квантово-размерных систем пониженной размерности

содержание темы 2

面 презентация по наноматериалах

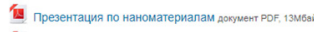

'夏 Асеев А. Л. Наноматериалы и нанотехнопогии для современной

попупроводниковой электроники

c.II Глоссарий по нанотехнологияи

'́. монодисперсные микросферы диоксида кремния с диаметром порядка 150 ны, комплексно самоорганизованные на плоской поверхности. Иообрахснияе (JPEG), 39.екбой

3. Сверхрешётки и размерное квантование

(1) содержание темы 3

4. Квантовые эффекты в квантово-размерных системах пониженной размерности

(1) содержание темы

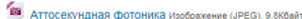

Написание научной статьи или проекта

7) WinDiview-2.0.2-Setup.exe

Рис. 4. Часть электронного курса «Введение в нанофизику», созданного в системе управления обучением MOODLE.

Таблица 1. Результаты педагогического эксперимента по курсу «Нанотехнологии и наноэлектроника», проведённого в 2014 году в экспериментальной группе 1.

\begin{tabular}{|c|c|c|c|c|}
\hline Студенты & Текущая сумма & Зачёт & Итоговая сумма & Итоговая оценка \\
\hline ФИ-11-03 & 104 & 0 & 104 & 3 \\
\hline ФИ-11-13 & 155 & 27 & 182 & 5 \\
\hline ФМ-11-11 & 83 & 19 & 102 & 3 \\
\hline ФИ-11-17 & 168 & 32 & 200 & 5 \\
\hline ФМ-11-15 & 155 & 32 & 187 & 5 \\
\hline ФМ-11-16 & 129 & 32 & 161 & 4 \\
\hline ФМ-11-17 & 64 & 10 & 74 & 3 \\
\hline ФМ-11-20 & 107 & 10 & 117 & 3 \\
\hline
\end{tabular}

В таблице 1 приведены результаты первого этапа педагогического эксперимента по курсу «Нанотехнологии и наноэлектроника», проведённого с 5.02.2014 по 30.05.2014 в рамках дисциплины по выбору со студентами из групп ФМ-11 и ФИ-11. Эту группу выбрали в качестве экспериментальной группы 1.

Первый этап педагогического эксперимента по курсу «Нанотехнологии и наноэлектроника» проводился с использованием таких информационных технологий, как электронный курс по дисциплине «Нанотехнологии и наноэлектроника», презентации к каждой лекции и интерактивные презентации. Перевод итоговой суммы баллов в итоговую оценку производился по шкале: от 181 до 200 баллов и соответствует оценке 5, от 141 до 180 баллов соответствуют оценке 4, от 61 до 140 баллов соответствуют оценке 3, от 0 до 60 баллов соответствуют оценке 2 .

Средний уровень обученности студентов по курсу «Нанотехнологии и наноэлектроника» 
в 2014 году составил 64 \%. Оптимальный уровень обученности (100\% - 64\%), допустимый уровень (64\% - 49\%), удовлетворительный уровень (48\% - 36\%), «тревожный» уровень (35\% - 20\%), критический уровень (19\% - 0\%). Полученное значение среднего уровня обученности студентов находится в области оптимальных значений. Так, из экспериментальной группы 1, состоящей из 8 человек, в первый год после выпуска работали в сфере образования 2 человека и 4 человека обучались в магистратуре педагогического направления подготовки. Из 4-х человек, обучавшихся в магистратуре педагогического направления подготовки, 2 человека (ФМ-11-15, ФМ-11-20) закончили с отличием магистратуру педагогического направления подготовки по магистерской программе «Приоритетные направления науки в физическом образовании».

Таблица 2. Результаты педагогического эксперимента по дисциплинам по выбору, читавшимся параллельно дисциплине по выбору «Нанотехнологии и наноэлектроника», проведённого в 2014 году в контрольной группе 1.

\begin{tabular}{|c|c|c|c|c|}
\hline Студенты & Текущая сумма & Зачёт & Итоговая сумма & Итоговая оценка \\
\hline ФМ-11-03 & 139 & 25 & 164 & 4 \\
\hline ФМ-11-06 & 87 & 10 & 97 & 3 \\
\hline ФМ-11-07 & 165 & 32 & 197 & 5 \\
\hline ФМ-11-08 & 131 & 20 & 151 & 4 \\
\hline ФМ-11-12 & 90 & 6 & 96 & 3 \\
\hline ФМ-11-01 & 83 & 10 & 93 & 3 \\
\hline ФМ-11-13 & 114 & 0 & 114 & 3 \\
\hline ФИ-11-01 & 79 & 0 & 79 & 3 \\
\hline ФИ-11-02 & 75 & 5 & 80 & 3 \\
\hline ФИ-11-04 & 160 & 31 & 191 & 5 \\
\hline ФИ-11-05 & 160 & 26 & 186 & 5 \\
\hline ФИ-11-06 & 50 & 20 & 70 & 3 \\
\hline ФИ-11-07 & 95 & 10 & 105 & 3 \\
\hline ФИ-11-08 & 90 & 6 & 96 & 3 \\
\hline ФИ-11-09 & 87 & 20 & 107 & 3 \\
\hline ФИ-11-10 & 158 & 20 & 178 & 4 \\
\hline ФИ-11-12 & 50 & 20 & 70 & 3 \\
\hline ФИ-11-15 & 157 & 30 & 187 & 5 \\
\hline ФИ-11-21 & 111 & 25 & 136 & 3 \\
\hline ФИ-11-16 & 97 & 20 & 117 & 3 \\
\hline ФИ-11-18 & 158 & 32 & 190 & 5 \\
\hline
\end{tabular}

В таблице 2 приведены результаты первого этапа педагогического эксперимента по курсу «Нанотехнологии и наноэлектроника», проведённого с 5.02.2014 по 30.05.2014 в рамках дисциплины по выбору со студентами из групп ФМ-11 и ФИ-11. Эту группу выбрали в качестве контрольной группы 1. Первый этап педагогического эксперимента. Средний уровень обученности студентов рассчитывался по стандартной формуле по итоговым оценкам по пятибалльной шкале. В 2014 году он составил 55 \%. Полученное значение среднего уровня обученности студентов находится в области допустимых значений. Значение показателя среднего уровня обученности студентов в контрольной группе 1 
значительно ниже значения показателя среднего уровня обученности студентов в экспериментальной группе 1 в 2014 году. Полученный результат подтверждает положительное влияние использования компьютерных технологий на уровень обученности студентов.

Таблица 3. Результаты педагогического эксперимента по курсу «Нанотехнологии и наноэлектроника», проведённого в 2015 году в экспериментальной группе 2.

\begin{tabular}{|c|c|c|c|c|}
\hline Студенты & Текущая сумма & Зачёт & Итоговая сумма & Итоговая оценка \\
\hline ФМ-12-10 & 142 & 32 & 174 & 5 \\
\hline ФМ-12-12 & 167 & 32 & 199 & 5 \\
\hline ФМ-12-01 & 136 & 1 & 137 & 3 \\
\hline ФМ-12-22 & 167 & 32 & 61 & 3 \\
\hline ФМ-12-15 & 60 & 1 & 71 & 3 \\
\hline ФМ-12-17 & 70 & 1 & 86 & 3 \\
\hline ФИ-12-08 & 85 & 1 & 83 & 3 \\
\hline ФМ-12-03 & 82 & 1 & 82 & 3 \\
\hline
\end{tabular}

В таблице 3 приведены результаты второго этапа педагогического эксперимента, проведённого с 3.02.2015 по 2.06.2015 в рамках дисциплины по выбору со студентами из групп ФМ-12 и ФИ-12. Эту группу выбрали в качестве экспериментальной группы 2. Второй этап педагогического эксперимента по курсу «Нанотехнологии и наноэлектроника» проводился с использованием таких информационных технологий, как электронный образовательный ресурс в виде электронного курса на платформе MOODLE, презентации к лекциям и интерактивные презентации. Средний уровень обученности студентов рассчитывался по стандартной формуле по итоговым оценкам по пятибалльной шкале. Средний уровень обученности студентов по курсу «Нанотехнологии и наноэлектроника» в 2014 году составил 57 \%. Полученное значение среднего уровня обученности студентов находится в области допустимых значений.

Таблица 4. Результаты педагогического эксперимента по дисциплинам по выбору, читавшимся параллельно дисциплине по выбору «Нанотехнологии и наноэлектроника», проведённого в 2015 году в контрольной группе 2.

\begin{tabular}{|c|c|c|c|c|}
\hline Студенты & Текущая сумма & Зачёт & Итоговая сумма & Итоговая оценка \\
\hline ФМ-12-02 & 91 & 10 & 101 & 3 \\
\hline ФМ-12-04 & 93 & 12 & 105 & 3 \\
\hline ФМ-12-07 & 60 & 1 & 61 & 3 \\
\hline ФМ-12-24 & 60 & 1 & 61 & 3 \\
\hline ФМ-12-23 & 148 & 11 & 159 & 4 \\
\hline ФМ-12-18 & 82 & 1 & 83 & 3 \\
\hline
\end{tabular}

В таблице 4 приведены результаты второго этапа педагогического эксперимента по курсу «Нанотехнологии и наноэлектроника», проведённого3.02.2015 по 2.06.2015 в рамках дисциплины по выбору со студентами из групп ФМ-12 и ФИ-12. Эту группу выбрали в качестве контрольной группы 2. Второй этап педагогического эксперимента проводился без использования информационных технологий в виде электронного курса и презентаций. 
Средний уровень обученности студентов рассчитывался по стандартной формуле по итоговым оценкам по пятибалльной шкале. Средний уровень обученности студентов по курсу «Нанотехнологии и наноэлектроника» в 2015 году составил 41 \%. Полученное значение среднего уровня обученности студентов находится в области допустимых значений. Значение показателя среднего уровня обученности студентов в контрольной группе 2 значительно ниже значения показателя среднего уровня обученности студентов в экспериментальной группе 2 в 2015 году. Полученный результат подтверждает положительное влияние использования компьютерных технологий на уровень обученности студентов.

Таблица 5. Результаты педагогического эксперимента по дисциплине по выбору «Нанотехнологии и наноэлектроника» в 2016 году в экспериментальной группе 3.

\begin{tabular}{|c|c|c|c|c|}
\hline Студенты & Текущая сумма & Зачёт & Итоговая сумма & Итоговая оценка \\
\hline ФМ-13-01 & 121 & 20 & 141 & 4 \\
\hline ФМ-13-02 & 121 & 30 & 151 & 4 \\
\hline ФМ-13-03 & 120 & 10 & 130 & 3 \\
\hline ФМ-13-06 & 130 & 25 & 155 & 4 \\
\hline ФМ-13-09 & 62 & 1 & 63 & 3 \\
\hline ФМ-13-13 & 74 & 1 & 75 & 3 \\
\hline ФМ-13-15 & 69 & 1 & 70 & 3 \\
\hline ФМ-13-18 & 61 & 1 & 62 & 3 \\
\hline ФИ-13-01 & 121 & 1 & 122 & 3 \\
\hline ФИ-13-02 & 164 & 32 & 196 & 5 \\
\hline ФИ-13-06 & 154 & 32 & 186 & 5 \\
\hline ФИ-13-08 & 107 & 25 & 132 & 3 \\
\hline ФИ-13-09 & 140 & 32 & 172 & 4 \\
\hline ФИ-13-14 & 118 & 1 & 119 & 3 \\
\hline ФИ-13-16 & 162 & 32 & 194 & 5 \\
\hline ФИ-13-17 & 74 & 1 & 75 & 3 \\
\hline
\end{tabular}

В таблице 5 приведены результаты третьего этапа педагогического эксперимента по курсу «Нанотехнологии и наноэлектроника», проведённого с 6.02.2016 по 27.05.2016 в рамках дисциплины по выбору со студентами из групп ФМ-13 и ФИ-13. Этугруппу выбрали в качестве экспериментальной группы 3. Третий этап педагогического эксперимента по курсу «Нанотехнологии и наноэлектроника» проводился с использованием таких информационных технологий, как электронный образовательный ресурс в виде электронного курса на платформе MOODLE, презентации к лекциям и интерактивные презентации. Средний уровень обученности студентов рассчитывался по стандартной формуле по итоговым оценкам по пятибалльной шкале. Средний уровень обученности студентов по курсу «Нанотехнологии и наноэлектроника» в 2016 году составил 55 \%. Полученное значение среднего уровня обученности студентов находится в области допустимых значений.

Таблица 6. Результаты педагогического эксперимента по дисциплинам по выбору, читавшимся параллельно дисциплине по выбору «Нанотехнологии и наноэлектроника» в 2016 году в контрольной группе 3.

\begin{tabular}{|c|c|c|c|c|}
\hline Студенты & Текущая сумма & Зачёт & Итоговая сумма & Итоговая оценка \\
\hline ФМ-13-04 & 125 & 32 & 157 & 4 \\
\hline
\end{tabular}




\begin{tabular}{|c|c|c|c|c|}
\hline ФМ-13-05 & 126 & 32 & 158 & 4 \\
\hline ФМ-13-07 & 100 & 24 & 124 & 3 \\
\hline ФМ-13-11 & 124 & 32 & 156 & 4 \\
\hline ФМ-13-12 & 110 & 25 & 135 & 3 \\
\hline ФМ-13-20 & 110 & 20 & 130 & 3 \\
\hline ФМ-13-16 & 130 & 32 & 162 & 4 \\
\hline ФМ-13-19 & 120 & 30 & 150 & 4 \\
\hline ФИ-13-05 & 90 & 20 & 110 & 3 \\
\hline ФИ-13-07 & 108 & 25 & 133 & 3 \\
\hline ФИ-13-10 & 100 & 20 & 120 & 3 \\
\hline ФИ-13-11 & 110 & 25 & 135 & 3 \\
\hline ФИ-13-12 & 81 & 22 & 103 & 3 \\
\hline ФИ-13-13 & 80 & 21 & 101 & 3 \\
\hline ФИ-13-15 & 120 & 30 & 150 & 4 \\
\hline ФИ-13-22 & 70 & 10 & 80 & 3 \\
\hline
\end{tabular}

В таблице 6 приведены результаты третьего этапа педагогического эксперимента по курсу «Нанотехнологии и наноэлектроника», проведённого с 6.02.2016 по 27.05.2016 в рамках дисциплины по выбору со студентами из групп ФМ-13 и ФИ-13. Эту группу выбрали в качестве контрольной группы 3. Третий этап педагогического эксперимента по курсу «Нанотехнологии и наноэлектроника» проводился без использования информационных технологий в виде электронного курса и презентаций. Средний уровень обученности студентов рассчитывался по стандартной формуле по итоговым оценкам по пятибалльной шкале. Средний уровень обученности студентов по курсу «Нанотехнологии и наноэлектроника» в 2016 году составил 47 \%. Полученное значение среднего уровня обученности студентов находится в области удовлетворительных значений. Значение показателя среднего уровня обученности студентов в контрольной группе 3 значительно ниже значения показателя среднего уровня обученности студентов в экспериментальной группе 3 в 2016 году. Полученный результат подтверждает положительное влияние использования компьютерных технологий в процессе обучения дисциплине по выбору «Нанотехнологии и наноэлектроника».

Таблица 7. Результаты педагогического эксперимента по дисциплине по выбору «Нанотехнологии и наноэлектроника» в 2017 году в экспериментальной группе 4.

\begin{tabular}{|c|c|c|c|c|}
\hline Студенты & Текущая сумма & Зачёт & Итоговая сумма & Итоговая оценка \\
\hline ФМ-14-04 & 168 & 32 & 200 & 5 \\
\hline ФМ-14-09 & 62 & 0 & 62 & 3 \\
\hline ФМ-14-11 & 136 & 30 & 166 & 4 \\
\hline ФМ-14-28 & 61 & 0 & 61 & 3 \\
\hline ФМ-14-16 & 168 & 32 & 200 & 5 \\
\hline ФМ-14-18 & 168 & 32 & 200 & 5 \\
\hline ФМ-14-19 & 84 & 0 & 84 & 3 \\
\hline ФМ-14-22 & 136 & 30 & 166 & 4 \\
\hline ФМ-14-24 & 96 & 25 & 121 & 3 \\
\hline
\end{tabular}


В таблице 7 приведены результаты четвёртого этапа педагогического эксперимента по курсу «Нанотехнологии и наноэлектроника», проведённого с 6.02.2017 по 27.05.2017 в рамках дисциплины по выбору со студентами из групп ФМ-14 и ФИ-14. Эту группу выбрали в качестве экспериментальной группы 4. Четвёртый этап педагогического эксперимента проводился с использованием таких информационных технологий, как электронный образовательный ресурс в виде электронного курса на платформе MOODLE, презентации к лекциям и интерактивные презентации. Средний уровень обученности студентов в 2017 году составил 64 \%. Полученное значение среднего уровня обученности студентов находится в области оптимальных значений.

Таблица 8. Результаты педагогического эксперимента по дисциплинам по выбору, читавшимся параллельно дисциплине по выбору «Нанотехнологии и наноэлектроника» в 2017 году в контрольной группе 4.

\begin{tabular}{|c|c|c|c|c|}
\hline Студенты & Текущая сумма & Зачёт & Итоговая сумма & Итоговая оценка \\
\hline ФМ-14-01 & 148 & 32 & 180 & 4 \\
\hline ФМ-14-02 & 130 & 30 & 160 & 4 \\
\hline ФМ-14-05 & 133 & 32 & 165 & 4 \\
\hline ФМ-14-07 & 129 & 25 & 154 & 4 \\
\hline ФМ-14-08 & 129 & 25 & 154 & 4 \\
\hline ФМ-14-10 & 134 & 32 & 166 & 4 \\
\hline ФМ-14-28 & 61 & 0 & 61 & 3 \\
\hline ФМ-14-15 & 133 & 30 & 163 & 4 \\
\hline ФМ-14-21 & 84 & 0 & 84 & 3 \\
\hline ФМ-14-23 & 60 & 5 & 65 & 3 \\
\hline ФИ-14-02 & 86 & 31 & 117 & 3 \\
\hline ФИ-14-04 & 74 & 32 & 106 & 3 \\
\hline ФИ-14-10 & 170 & 0 & 170 & 3 \\
\hline ФИ-14-12 & 53 & 11 & 64 & 3 \\
\hline ФИ-14-14 & 51 & 10 & 61 & 3 \\
\hline ФИ-14-15 & 60 & 7 & 67 & 3 \\
\hline ФИ-14-17 & 61 & 0 & 61 & 3 \\
\hline ФИ-14-21 & 90 & 0 & 90 & 3 \\
\hline ФИ-14-23 & 130 & 0 & 130 & 3 \\
\hline
\end{tabular}

В таблице 8 представлены результаты педагогического эксперимента по дисциплинам по выбору, читавшимся параллельно учебной дисциплине по выбору «Нанотехнологии и наноэлектроника» в 2017 году в контрольной группе 4. Средний уровень обученности студентов в контрольной группе 4 в 2017 году составил 46 \%. Полученное значение среднего уровня обученности студентов находится в области удовлетворительных значений. Значение показателя среднего уровня обученности студентов в контрольной группе 4 гораздо ниже значения показателя среднего уровня обученности студентов в экспериментальной группе. Полученный в 2017 году результат подтверждает положительное влияние использования компьютерных технологий в процессе обучения дисциплине по выбору «Нанотехнологии и наноэлектроника». 
Таблица 9. Результаты педагогического эксперимента по курсу «Введение в нанофизику» в 2018 году в экспериментальной группе 5 .

\begin{tabular}{|c|c|c|c|c|}
\hline Студенты & Текущая сумма & Зачёт & Итоговая сумма & Итоговая оценка \\
\hline ФМ-15-02 & 167 & 32 & 199 & 5 \\
\hline ФМ-15-08 & 168 & 32 & 200 & 5 \\
\hline ФМ-15-18 & 168 & 32 & 200 & 5 \\
\hline ФМ-15-19 & 141 & 32 & 173 & 4 \\
\hline ФМ-15-11 & 100 & 1 & 101 & 3 \\
\hline
\end{tabular}

В таблице 9 приведены результаты пятого этапа педагогического эксперимента по курсу «Введение в нанофизику», проведённого с 24.01.2018 по 16.05.2018 в рамках дисциплины по выбору со студентами из групп ФМ-15. Эту группу выбрали в качестве экспериментальной группы 5. Средний уровень обученности студентов экспериментальной группы 5 в 2018 году составил 80 \%. Полученное значение среднего уровня обученности студентов находится в области оптимальных значений.

Таблица 10. Результаты педагогического эксперимента по дисциплинам по выбору, читавшимся параллельно дисциплине по выбору «Введение в нанофизику» в 2018 году в контрольной группе 5.

\begin{tabular}{|c|c|c|c|c|}
\hline Студенты & Текущая сумма & Зачёт & Итоговая сумма & Итоговая оценка \\
\hline ФМ-15-01 & 110 & 0 & 110 & 3 \\
\hline ФМ-15-03 & 121 & 0 & 121 & 3 \\
\hline ФМ-15-04 & 109 & 12 & 121 & 3 \\
\hline ФМ-15-05 & 118 & 0 & 118 & 3 \\
\hline ФМ-15-06 & 128 & 0 & 128 & 3 \\
\hline ФМ-15-07 & 102 & 0 & 102 & 3 \\
\hline ФМ-15-14 & 113 & 0 & 113 & 3 \\
\hline ФМ-15-15 & 107 & 0 & 107 & 3 \\
\hline ФМ-15-17 & 106 & 0 & 106 & 3 \\
\hline ФМ-15-20 & 101 & 0 & 101 & 3 \\
\hline ФМ-15-22 & 112 & 14 & 126 & 3 \\
\hline ФМ-15-24 & 122 & 0 & 0 & 3 \\
\hline
\end{tabular}

В таблице 10 приведены результаты пятого этапа педагогического эксперимента в контрольной группе 5 (период с 24.01.2018 по 16.05.2018). Средний уровень обученности студентов контрольной группы 5 в 2018 году составил 36 \%. Полученное значение среднего уровня обученности студентов находится в области удовлетворительных значений. 2018 год показал: значение показателя среднего уровня обученности студентов в контрольной группе гораздо ниже значения показателя среднего уровня обученности студентов в экспериментальной группе. Полученный результат подтверждает положительное влияние использования компьютерных технологий в процессе обучения дисциплине по выбору «Введение в нанофизику» на успеваемость студентов.

На рис. 1 представлены результаты проведённого педагогического эксперимента в виде графика среднего уровня обученности студентов (в процентах) в экспериментальной и контрольной группах по годам чтения дисциплин по выбору «Введение в нанофизику» и «Нанотехнологии и наноэлектроника» в экспериментальной группе и параллельных 


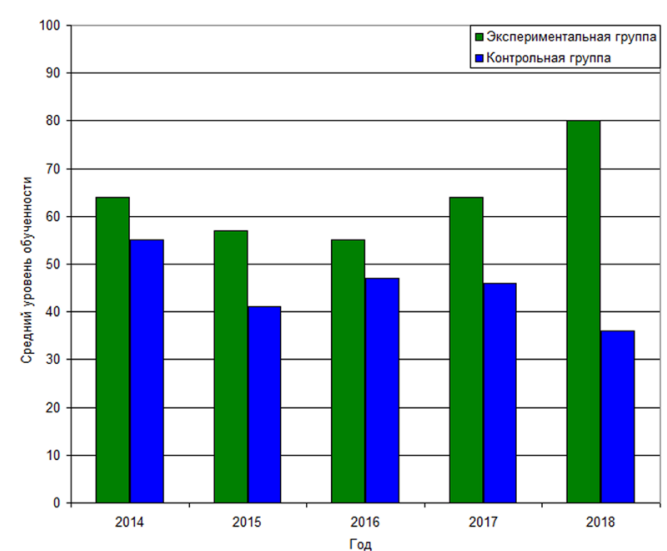

Рис. 1. Распределение среднего уровня обученности студентов в экспериментальной и контрольной группах по годам чтения дисциплин по выбору «Введение в нанофизику» и «Нанотехнологии и наноэлектроника» в экспериментальной группе и параллельных дисциплин в контрольной группе. дисциплин в контрольной группе. Видно, что экспериментальная группа демонстрирует более высокий уровень обученности на протяжении всего педагогического эксперимента.

Некоторые выводы. Сопоставление результатов изучения «Нанотехнологии и наноэлектроника» и «Введение в нанофизику» без применения и с применением электронных информационных средств обучения студентами групп по профилям подготовки «Физика. Математика» и «Физика. Информатика» на факультете физико-математического и технологического образования в течение 4-х лет доказывает эффективность применения информационных технологий в процессе преподавания учебных дисциплин, связанных с нанотехнологиями и наноэлектроникой.

Использование электронного курса по дисциплинам по выбору «Нанотехнологии и наноэлектроника» и «Введение в нанофизику» в процессе преподавания физико-технических основ нанотехнологии и наноэлектроники возможно на всех этапах деятельности, начиная с этапа целеполагания и заканчивая этапом рефлексии и практикования.

Увеличение компетентности студентов в области физико-технических основ нанотехнологий подтверждается результатами диагностики уровня их обученности за несколько лет обучения. В результате сравнения среднего уровня обученности различных групп студентов (профили «Физика. Математика» и «Физика. Информатика») получено достоверно значимое подтверждение гипотезы о том, что внедрение информационных технологий, и, в частности, электронного курса в образовательную программу положительно влияет на уровень обученности студентов, изучающих дисциплины по выбору «Нанотехнологии и наноэлектроника» и «Введение в нанофизику».

\section{Источники и литература:}

1. Алтунин К. К. Разработка электронного образовательного ресурса в университете при помощи инструментов Google Site и MOODLE. // Поволжский педагогический поиск. 2017. № 3 (21). С. 116 - 124.

2. Алтунин К. К. Разработка информационного сопровождения изучения темы, посвященной изучению приближения эффективной среды в курсе нанооптики. // Наука online. 2018. № 3 (4), с. 80 - 94. [Электронный ресурc].// URL: http://journal-no.ulspu.ru/wp-content/uploads/2018/10/Altunin3_2018.pdf (дата обращения 14.12.2018).

3. Алтунин К. К., Макушкина К. И. Разработка электронного образовательного ресурса по курсу «Нанотехнологии оптических материалов». // В сборнике: Актуальные вопросы преподавания технических дисциплин. Материалы Всероссийской научно-практической конференции. 2018. С. 47 - 50.

4. Алтунин К. К., Низамова А. Р. Разработка интерактивной презентации по элементам наноплазмоники в курсе физики. // Материалы Всероссийской научно-практической конференции «Актуальные вопросы преподавания технических дисциплин», 15 июня 2018 г., выпуск 3. Ульяновск: УлГПУ, 2018. с. 8 - 10.

5. Байнева И. И., Байнев В.В.Применение информационно-компьютерных технологий в новых образовательных программах. // Учебный эксперимент в образовании. 2011. № 4. С. 38 - 41.

6. Дворянчиков Н. В., Калашникова Т. В., Печникова Л. С., Фролова Н. В. Использование электронного обучения в образовательном процессе: проблемы и перспективы. // Психологическая наука и образование. 2016. T. 21. № 2. С. $76-83$

7. Михайлюк М. И. Особенности структуры профессиональной подготовки будущих инженеров в области 
наноэлектроники. // Фундаментальные и прикладные исследования: проблемы и результаты. 2012. № 2. С. 35 - 39.

8. Морев Д. Е. Современное состояние подготовки специалистов в области нанотехнологий в России. // Психолого-педагогический журнал «Гаудеамус». 2011. Т. 1. № 17. С. 94 - 100.

9. Надеждин Е.Н. Современные проблемы подготовки специалистов в области нанотехнологий. // Ученые записки ИИО РАО. 2010. № 33. С. 22 - 57.

10. Осипов Д.А. О сильных и слабых сторонах электронного обучения. // Научное сообщество студентов XXI столетия. Технические науки: сборник статей по материалам V-ой международной студенческой научно-практической конференции. Новосибирск, 22 октября 2012 г. №5. [Электронный ресурc].// URL: http:// sibac.info/archive/technic/5.pdf (дата обращения 14.12.2018).

11. Остроумова Ю. С. Физические основы и достижения современных наукоемких технологий в содержании уровневой подготовки педагогических кадров // Физическое образование в ВУЗах. 2014. Т. 20 . № 1. С. 89 - 97.

12. Приседский В. В., Волкова Е. И. Опыт преподавания курса «Наноматериалы и нанотехнологии» для студентов инженерных специальностей. // Вестник Донецкого национального университета. Серия: Гуманитарные науки. 2018. № 1. С. 225 - 231.

13. Чванова М.С., Морев Д. Е., Молчанов А. А. Дистанционные образовательные технологии в управлении восприятием новых знаний студентами-гуманитариями (на примере нанотехнологий). // Образовательные технологии и общество. 2014. Т. 17. № 3. С. 509 - 534.

14. Юнусов Р.Ф., Кормильцев Н. В. Электронный курс по наноматериалам и нанотехнологим. // Современные научные исследования и разработки. 2016. № 3 (3). С. 135 - 141. 